\title{
JOY AND MEMORY: HAPPINESS AND THE CELEBRATION OF LIFE
}

In Happiness And Contemporary Society : Conference Proceedings Volume (Lviv, March, 20-21, 2021). Lviv: SPOLOM, 2021. P. 205-207. https://doi.org/10.31108/7.2021.46

ISBN 978-966-919-697-2 
https://doi.org/10.31108/7.2021.46

\author{
MOSCHINI Marco \\ PhD, Associate Professor \\ Department of Philosophy, Social Science and Education \\ University of Perugia (Perugia, Italy)
}

\title{
JOY AND MEMORY: HAPPINESS AND THE CELEBRATION OF LIFE
}

The festive and celebratory attitude, typical of women and men, is a sign of a profound gift of happiness. Happiness preserves joy and expresses the desire to celebrate life in joy. Our happy moments in life are celebrated because they are given by happiness is produced by this festive memory. It is therefore necessary to rediscover the true meaning of celebration and beaty of personal and community life.

On regard this second conference on Happiness in our contemporary time, after having clarified the relation between happiness and the person during the first conference, I return to a central topic to focus the concept of happiness within a particular question about joy and celebration in human experience. Joy and celebration (rejoicing) are in fact the external elements of happiness and it is precisely an absence of happiness that has deprived man of a human celebration, meaning the celebration as the feast that everybody lives to make memory of the salient moments of personal and community life.

The topic must define the "humane" and "inhumane" way of celebrating. It would be very easy to start from the negative what appears inhumane today. Making a list of the negative might be easy, but it seems to me that doing so would start very badly. In fact, I feel that such an approach always carries out to emphasis on the less positive side of the human situation today. It makes us start from an original pessimism. Instead, it is good to face the issue of the human by leaving the too biological dimension linked to this adjective. It is better to start from the positive and from the exercise of focus our attention to the beauty that is manifested in everything that is authentically human. It must always be kept in mind that emerges, in the deepest authenticity of man's spiritual roots, man's lovable positivity. The lovable beauty that always overcomes the terrible, ugly, evil sign, which generates the violence, the inability to love and the need for human abuse and falsify.

Man is a magnificent dream; it is the word that address to a universe full of values, of stories, of telling. "Human reality" is the word that refers to that magnificent "project": the person. A single unrepeatable, unique and irreplaceable. The person is not something static, given, he is someone who expresses himself in life which is always compound of encounters, dialogues, good and adverse fate, which always help you to get out of unsafe territories, from reduced horizons.

The person is a good "project", a forward projection, a singular future that meets a community. Being a person means being unique, full of meaning, a voice of stories that come from the unique experience that everyone is. The person is that world, that life, that made us up for how we are and for what we are. And this life we are called to share fully with others. Man is love received and received in a unique way; but it is also love given and offered.

Nobodies are what we are if we stand "outside" or are displaced from the plot of our relationships; from the stories that have determined us; everyone is dimensioned by "what it is and what it will be", as a being that is realized in continuous change of life. Always open to the other, to history, to the free dimension of encounter and gift. The person for this is, and remains, 
the dream of life, and we are this dream that we dream every time. Man and woman are the single person. The person imposing himself, giving himself. The person is the giving of everyone as a project for all; lived project that manifests itself as a concrete development of potential and capacities that everybody has in a special way and not for himself but always for all. The person is the happiness received and given.

The person "flourishes" reaching the great goals, the highest goals of a truer and a higher humanity. We are fighting for this height and to make this leap upward we must exercise the great virtues: the love, the hope, the faith; these virtues must never stagger; the courage, the strength, the ability to regulate oneself help in this fight. But the leap to the promised height passes from the daily exercise of the little virtues, from familiarity with our feelings, with the continuous and certain reference search with what we feel. We need the little virtue of thanksgiving to remind us those have given us cause for joy, for reflection, for pushing forward in the dark. We need to cultivate the virtue of a memory capable of always making us relive the radical feeling experienced in the important moments of life. That memory that makes us relive the joy, the pain, the presence, the absence, and all the other stages in which we felt alive.

We need to tell and tell everything that matter to us and without which there not would-be authentic relationship. We need our every action to tell us, what we can be and what we are, and we will be. We need to have happy experiences and to give that happiness.

Shortly, the person needs small, but solid, remembrance exercises that nourish the happy substance of the human in us. To remember means to cultivate, with recurrence, the memory that we are men and women with unrepeatable characteristic, capabilities and stories, no longer replicable. We are human; we know that every single cell of ours is the biological sign of an existence that is much more than biological life. We are also biology... but we are much more than biology: we are emotion, imagination, research, desire and nostalgia and challenge for what surpasses and dominates us. The person is himself in referring to even the smallest gesture of gratitude for those who are our companion in adventure or misfortune. We are in need of loving and grateful expression. We are who participate our illusions as if they were realities, and live reality as if it were the illusion that takes form. This game of memory, respect, thanksgiving and nostalgia is the daily and beautiful dimension that contrasts with forgetfulness, tired repetition, absence of attention and ruinous indifference which often seems to overwhelm the men; and for this reason, our contemporary time seems to show us so much inhumanity, so much counterfeiting of the human.

This genuine effort to elevate the self that procures happiness and is expresses in a festive attitude. In the moment of serenity and gratuitousness, in the joy. The moments in which these small and large values are recognized as moments worthy of remembrance and therefore worthy of the celebration.

There is not celebration that is not the celebration of remembrance and joy, and it does not matter if this is a joyful or painful remembrance. Celebration is the moment in which return emotions, sensations, dreams, tastes and even words to us for which we are moved to gratitude, to happiness. There is certainly no reason to remember something without a reason for grateful thought going hand in hand. The memory of what truly be important inevitably moves us to recognize that we need to thanksgiving. We need to break, to reflect, on our lives and recognize that we are never alone and that we must say a word of heartfelt thanks to someone who has helped us to be better.

There is not celebration without memory and thanksgiving. But both dimensions cannot fail to evoke the need to rejoice and there is no joy except in sharing joy and happiness. It is celebrated to take part serenity, joy, gratitude. The celebration is a participation. 
The celebration is the act of rejoicing together. Opening of the heart that over time wants that what matters in life does not pass, that it returns. Finding a space where we all recur to find ourselves together to relive again the joy. The celebration of moments individual and communitarian then becomes a moment not only of serenity, but an exercise of gratuitousness. And in it, peace and joy are given to us through the concreteness of gesture, food, flavor, song, kind think, rituals; that become a celebration of the significant and lively moment for which our soul rejoices.

The celebration therefore binds us even more to the infinite network of those who not only rejoice with us, but also those who are no longer there. It is the expansion of the spirit but also the expansion of communion. The content of joy is gathered in the form of celebration; Everything becomes and gives substance to the great chain of tradition. The "always" that does not set becomes the happy moment of today.

We cannot be without the celebration because it would mean giving up and losing the ability to be able to failure. We can win our fight against the time with a moment of joy and happiness. The celebration is the victory of the rare and happy moment over the series of our ordinariness, of our predictable things, of our inconclusive hours too similar to themselves. It is the recovery of what is noble and great; to suspend the obvious and renounce the heaviness of existence, in favor of the right that opening up to the light spirit has over us.

We are called to happiness, and this must be forever. Living the celebration is like having an announcement of that goal. It is an anticipation and a kind of pre-realization of a reality that awaits us and the concrete presentation of a world that appears to us, in joy: A world not only possible but also real.

We have the duty to preserve this deep dimension of the festive attitude. We must preserve it from the contemporary oblivion of the human dimensions. In these times is very easy forgetting what condemn to remain lower and lower. It seems that we are condemned to keep our "steps low"; not to rise, and we are forced to reduce everything in our life to the minimum degree. Almost obliged to reduce everything to profit and so we are forced to flatten everything, to restrict everything to the exclusive moment of the event.

We just know that we are destined to become witnesses of the reappropriation of ourselves; we know that we must protect everything that is human, authentically human. And so, we should keep the deeply human "sacredness" of the celebration of life, because we must keep this greed of joy that moves from the awareness that there is something higher that makes the heart happy. We must protect, within the ordinariness of our chronology, the time of the spirit, which is the time devoted to elevating what makes man happy; this is the time so that in the tranquility can be fully free to rejoice.

This is the sign of celebration joyful that we should always take care to live and bring to life; this festive attitude preserves happiness. In the time of sadness and efficiency, we should claim as a right that of being able to stop for a while to contemplate, in the flow of life, the memory of the constitutive events of our existence, the great achievements of our spirit, the gifts of happiness that is character of everyone. And we must carry out this goal of preserving the spirit of the happiness, because we no longer consent our generation to forget about themselves; the life asks to be lived consciously in joy and thanksgiving. 